\title{
Link and Match Between Hypnoteaching and Transformative Learning, A Study Toward Practical Dimension in Learning
}

\author{
Fuad Hasan, Sukidin \\ Faculty of Teacher Training and Education, University of Jember \\ e-mail: fuadhasan@unej.ac.id
}

\author{
Received: 12 Januari 2021; Revised: 26 Februari 2021; Accepted: 28 April 2021 \\ DOI: http://dx.doi.org/10.37905/aksara.7.2.405-412.2021
}

\begin{abstract}
Abstrak
Hypnoteaching merupakan salah satu metode pembelajaran yang memiliki tujuan yang sama dengan pembelajaran transformative, yaitu merubah mindset sasarannya yang dalam konteks ini adalah mahasiswa. Penelitian ini bertujuan untuk mengevaluasi kesesuaian dari metode hypnoteaching dan transformative learning ditinjau dari sisi input, proses dan hasil. Langkah-langkah penelitian yang ditempuh adalah melakukan studi pendahuluan, pengumpulan data, analisis data dan penarikan kesimpulan. Hasil penelitian menunjukan bahwa (1) dari sisi input, pendidik memiliki kualifikasi yang sesuai dari sisi penguasaan metode hypnoteaching namun belum memahami komponen pembelajaran transformatif, (2) dari sisi proses, langkah-langkah pembelajaran transformative tidak sepenuhnya tercover dalam langkah-langkah metode hypnoteaching dan (3) dari sisi hasil, dampak instruksional berupa pemerolehan sikap kritis telah tercapai, sedangkan dampak pengiring berupa peningkatan capaian prestasi masih sangat sedikit jika ditinjau dari sisi jumlah baik dari sisi keikutsertaan dalam event prestasi dan jumlah penghargaan yang diperoleh.
\end{abstract}

Kata Kunci

Sikap kritis, hypnoteaching, transformative learning, mahasiswa.

\begin{abstract}
Hypnoteaching is a learning method that has a same purpose with transformative learning which is to transform the mindset of student as its target. This study aims to evaluate the suitability of hypnoteaching and transformative learning in terms of input, process and results. The steps of research that were done are conducting a preliminary study, collecting data, analyzing data and drawing conclusions. The results showed that (1) from the input side, educators had the appropriate qualifications in terms of mastery of the hypnoteaching method but did not yet understand the components of transformative learning, (2) in terms of the process, transformative learning steps were not fully covered in the steps of the hypnoteaching method and (3) in terms of results, the instructional impact in the form of obtaining a critical attitude has been achieved, while the accompanying impact in the form of increased achievement is still very small when viewed in terms of numbers both in terms of participation in achievement events and the number of awards received.
\end{abstract}

Keyword:

Critical attitude, hypnoteaching, transformative learning, student in higher education 


\section{INTRODUCTION}

The issues about bonus demography is one of hot topic in Indonesia. Bonus demography can be defined as a condition where the number of productive people (based on age) is massive. However bonus demography is also seen as double edge sword which has opportunity in one side and the threat at the other side. Bonus demography become opportunity when the people at the productive age has skills that make them able to survive (become productive and innovative) so they can manage and lead their own live and the society while bonus demography become threat when they luck on those skills.

As response to bonus demography issues, Indonesia government put the burden on education. It is stated on the opening of UUD 1945 which is also emphasized on article 31 paragraph 1 to 5 which means that every citizen has the right to education that is supported and facilitated by the government. By looking at the target in the years of 2030, higher education become the main resource in preparing human resource for 2030 because the student in higher education today will be the people who will replace the previous generation in 10 years in front, and in realizing that, the higher education provider proceed it in the frame work of pedagogy.

Aside of the characteristic on every scientific field, learning is a complex thing. Learning is not only about transfer of knowledge but also transfer of learning that can result the transformation toward mindset and the action pattern (Novak \& Gowin, 2004). In the context of student in higher education, the learning should be designed to make student become competence to realize the result of study into attitude in real life (Abdulhak, 2007). The capacity of intellectual that is built in the system of learning should be directed toward increasing capacity in self-managing and managing environment (Hardika, 2014).

As the response of those condition, the study of transformative learning bargain a concept as an alternative toward learning practice to change the mental attitude of student. Transformative learning study in education has resulted some of learning model with different target/object. Some researcher who focused their transformative learning study on student in higher education and the young people are Hardika (2014) and then followed by Hasan (2015) and Anggreini (2016) that used karang taruna as the main subject to develop transformative learning model. The implementation of transformative learning model can be done by using some learning methods.

The implementation of transformative learning can be done by various methods, and hypnoteaching method is seen as one of the potential method that can support the success of transformative learning. That hypothesis is taken based on the previous research which found that the hypnoteaching method has contribute to increase students motivation in learning English (Hasbullah \& Rahmawati, 2015). It also has big contribution in delivering the material about belief and character (Miftakhurrozaq, 2018).

The result of preliminary study found that there are some lecturer who uses hypnoteaching method in Faculty of Teacher Training and Education, University of Jember. It was confirmed that the use of that method is to change the mind set of student in higher education where they teach. This method has been used since 2016 but there is no proper research that was conducted to see the result nor the impact.

Due to the similarity between the goals of hypnoteaching and transformative learning, this research try to evaluate the match between hypnoteaching method and 
transformative learning that is seen from input, process and output. In doing so, researcher delve into practical dimension from the lecturer who use hypnoteaching methods in his learning process.

\section{Method}

This study adapt qualitative approach by using case study design. The steps in this research are (1) doing preliminary research, (2) data collecting, (3) data analysis, and (4) taking research conclusion. The preliminary research is done to make sure that the object is available and able to be researched. the preliminary research is done by study literature and interview with the lecturer who use hypnoteaching method.

Data collecting is done through observation, interview and questionaire. The observation is done to collect the data about how hypnoteaching method is implemented into learning process. The interview is done to collect the data about how far the lecturer understand about transformative learning and also to validate the data that was collected through observation. And questionnaire is done to collect the critical attitude of student as the result of implementing the method.

The data analysis is done by adopting Miles, Huberman \& Saldana (2018) which are data reduction, data display and taking conclussion. Data reduction is process in doing reduction on certain aspects of data, typically the volume of data (Zang, 2009). Data display is process in arranging a group of information into understandable form. Taking conclusion is formularization process of preposition related to principal, appoint it as research funding, and then evaluate it over and over.

\section{RESULT AND DISCUSSION Result}

This part present information related to the measurement results of the process input and output. Input evaluation is carried out by looking at the competence and understanding of educators regarding hypnoteaching and transformative learning methods. Process evaluation is seen from the application of the hypnoteaching method and the steps of transformative learning, while the evaluation of the output is seen from the instructional impact and the accompanying impact produced after learning.

The results of the input evaluation show that educators have the appropriate qualifications in terms of mastery of the hypnoteaching method but do not yet understand the components of transformative learning. Educators have earned various degrees from hypnosis methods to instructor level. In practice, educators are also very qualified in applying every step of the hypnoteaching method. However, educators do not have sufficient information regarding transformative learning and transformative learning models.

The results of the process evaluation show that educators have implemented every step of the hypnoteaching method. However, these steps do not fully cover the steps that exist in the transformative learning model. The steps of the hpnoteaching method consist of pre-induction, induction, deepening, depth level test, suggestion, termination, and posthypnotic, while the transformative learning steps are approach, problem determination, development of critical reflection, determination of action, implementation of action and evaluation (Hasan, 2017). 
The comparison of the application of the steps of the hypnoteaching method and the transformative learning model can be seen in the following table

Table 1. The Comparison of Hypnoteaching Steps and Transformative Learning Steps

\begin{tabular}{|c|c|c|}
\hline No. & $\begin{array}{l}\text { Steps of } \\
\text { hypnoteaching }\end{array}$ & $\begin{array}{l}\text { Steps of transformative } \\
\text { learning }\end{array}$ \\
\hline 1. & Pre-Induction & Approaching \\
\hline 2. & Induction & Problem determination \\
\hline 3. & Deepening & $\begin{array}{l}\text { Developing critical } \\
\text { reflection }\end{array}$ \\
\hline 4. & Depth level test & Deciding action \\
\hline 5 & Suggestion & Action \\
\hline 6 & Termination & Evaluation \\
\hline 7 & Post-hypnotic & \\
\hline
\end{tabular}

The results of the evaluation of the output consist of instructional impacts and accompaniment impacts. The instructional impact in the form of obtaining a critical attitude has been achieved, while the accompanying impact in the form of an increase in achievement is still very low when viewed in terms of both the number of participation in achievement events and the number of awards that was achieved.

The results of the instructional impact can be seen from the achievement of students' critical attitudes in terms of discipline, hard work, creativity, curiosity, environmental care and responsibility. Measurements were made through a questionnaire with details of 6 questions for aspects of discipline and curiosity, 5 questions for aspects of hard work and environmental care, and 4 questions for creative and responsibility aspects.

The results of the measurement of 66 respondents showed that in general, the implementation of the hypnoteaching method had improved the critical attitude of students in good categories. The details are the average score in the discipline aspect is 24 , the average score in the hard work aspect is 20 , the average score in the creativity aspect is 12 , the average score in the curiosity aspect is 22 , the average score in the environmental aspect is 19 , and the average score in the responsibility aspect is 18 .

Table 2. The Result of Critical Attitude of Student

\begin{tabular}{llll}
\hline No. & Aspect & Mean & Category \\
\hline 1. & Discipline & 24 & Good \\
2. & Hard work & 20 & Good \\
3. & Creativity & 12 & Good \\
4. & Curiousity & 22 & Good \\
5 & Environtmental care & 19 & Good \\
6 & Responsibility & 18 & Very good \\
7 & All aspect & 115 & Good \\
\hline
\end{tabular}

\section{Discussion}

\section{The Simmilarity of Hypnoteaching method with transformative learning}

Hypnoteaching is a method a learning method that combines the teaching and learning process with hypnosis (Istiani \& Islamy, 2020). The similarities between the hypnoteaching method and transformative learning can be seen in the aspects of goals, processes and results. The purpose of applying the hypnoteacing method is to achieve maximum learning outcomes through the change of mind set made from the 
subconscious. This is in line with the goal of transformative learning, namely changing the mind set of students so that they can produce maximum learning outcomes (Hasan, 2017).

Change in the transformative perspective has the meaning of changing form or incarnating, such as in the context of converting heat into energy (Echols \& Shadily in Hasan (2015). Daszko, Macur \& Sheinberg in Hasan (2015) states "To transform means to change in form, appearance or structure; metamorphoses; to change condition, nature or character; to change into another substance. Based on this explanation, change in transformative is changing something from its form, appearance, arrangement, condition, or character to its original form. Moedzakir (2010) also stated that learning that does not produce fundamental changes in students is not transformative learning. In the context of a transformative learning model, the impact of the instruction is a change in the mindset of the student.

The next equation lies in the process side where the hypnoteaching method and transformative learning have an initial stage in the form of approaching the target. The approach in the hypnoteaching method is termed as pre-induction which is carried out through report card building with the aim of creating closeness and trust. This process in transformative learning called as an approach phase which also aims to establish closeness with students (Hasan, 2017)

Learning outcomes are what make hypnoteaching and transformative learning methods is able to go hand in hand. Both the hypnoteaching and transformative learning methods expect permanent learning outcomes or change in the mind set so that they become the basis for achieving other positive things. Mind sets are simple beliefs that have the power to change psychology (thoughts, awareness, feelings, attitudes, etc.) (Dwek, 2006, Ramadhan, 2016)

\section{The Different of Hypnoteaching method with transformative learning}

The difference between the hypnoteaching and transformative learning methods includes differences in the roles of educators and students, the process and the description of the results. In the hypnoteaching method, educators have an active role in almost every action so that its existence is relatively difficult to replace. Noer (2010) stated one of seven unsure that is needed to be keeped in mind by the one who want to applied hypnoteaching are educator appearance, sympathy, empathy, use of language, motivation, modeling and self control. The application of the hypnoteaching method emphasizes the use of positive words or positive suggestions from educators as one of the strengths or keys to its success (Istiani \& Islamy, 2020).

As for transformative learning, educators act more as facilitators who facilitate each stage rather than as the actor. Taylor \& Cranton (2013) stated that a concept that is most central to transformative learning is experience. That is why when facilitator should be able to provide the meaningful experience that support the process of transformation. However, the existence of facilitator can be done by the teacher or maybe the student themselves.

The other difference between hypnoteaching and transformative learning lies in the learning process. The hypnoteaching method involves the subconscious as one of its core processes (Jaya, 2010), whereas transformative learning involves aspects of the conscious mind or reality in the process of change (Hasan, 2015). Taylor \& Cranton 
(2013) stated that experience is

The learning outcomes also become the difference between hypnoteaching and transformative learning. In the hypnoteaching, the learning outcomes lie in the extent to which the subconscious influences students' conscious minds. The subconscious influence is often strong after the hypnosis process and tends to weaken as the conscious mind strengthens. Especially if the conscious mind in this context is the reality that is captured through the five senses which has a significant difference, then the effect of hypnosis will tend to weaken. In this context, giving suggestions must continue to be given so that learning outcomes are always maintained.

As for transformative learning, learning outcomes are found in changes in the mind set / term of reference which are the basis for every action that will be taken. Along with changes in the mind set that cannot be instantaneous or take a long time to be achieved, learning outcomes in transformative learning are also much more durable, the same condition is also applied to the effect of its learning out come.

Another differentiator is lies in the evaluation process. The evaluation of the hypnoteaching method lies more in the results with the role of educators is still quite dominant as evaluator compared to the transformative learning. Evaluation in transformative learning is related to the things that take place during and after transformative learning is implemented. Students act as evaluators in each process while educators still act as facilitators. Its mean that student is become the main actor in the whole process of transformative learning phase.

\section{CONCLUSION}

Qualifications and also the role of educators who apply the hypnoteaching method have a big opportunity in the success of changing the mindset which is the goal of transformative learning. Giving positive suggestions as the power of the hypnoteaching method can be a significant contribution in keeping the goals of each transformative stage always on track. The results of the hypnoteaching method in the form of high motivation/enthusiasm, self-confidence, feeling relaxed, and other positive conditions become the opening gate for the change in the mind set of students. Learning outcomes which are the influence of the subconscious must be combined with the conscious state so that changes to the mindset can actually occur.

\section{REFERENCE}

Abdulhak, I. 2007. Teknologi Pendidikan dalam Ilmu dan Aplikasi Pendidikan. Bandung: Pedagogiana Press.

Anggraeni, Y. 2016. Model Solusi dan Panduan Implementasi Pembelajaran Transformatif pada Program Pembinaan Karang Taruna. Tesis. Malang. Pascasarjana Universitas Negeri Malang

Dweck, CS. (2006). Mindset: The New Psychology of Succes. Jakarta: PT Serambi Ilmu Semesta

Hardika. 2014. Model Pembelajaran Transformatif Berbasis Learning How To Learn Untuk Peningkatan Kreatifitas Belajar Mahasiswa. Madrasah, Vol. 6, No. 2, Januari-Juni 2014 
Hasan, F. 2015. Pengembangan Model Pembelejaran Transformatif untuk Program Pembinaan Karangtaruna. Tesis. Malang. Pascasarjana Universitas Negeri Malang

Hasan, F. 2017. Model Pembinaan Transformatif untuk Program Pembinaan Karang Taruna. Universitas Jember. Pancaran Pendidikan Vol 6, No. 1, hal 179-192, Februari 2017

Hasbullah \& Rahmawati, E. Y. 2015. Pengaruh Penerapan Metode Hypnoteaching Terhadap Motivasi Belajar Mahasiswa Universitas Indraprasta PGRI. Jurnal Formatif 5 (1) : 83-90, 2015

Istiani, N \& Islamy, A. (2020). Hypnoteaching Sebagai Metode Alternatif dalam Pembelajaran Materi Keagamaan, Kjian Konsep dan Teknis pada Pembelajaran Spiritual. Sustainable, Jurnal Kajian Mutu Pendidikan Volume 03 Nomor 02 Tahun 2020 https://doi.org/10.32923/kjmp.v3i2.1382

Jaya, N. T. 2010. Hypnoteaching Bukan Sekedar Mengajar. Bekasi: D-Brain

Moedzakir, M. D. 2010. Metode Pembelajaran untuk Program-Program Pendidikan Luar Sekolah. Malang: UM Press

Miftakhurozaq. 2018. Implementasi Metode Hypnoteaching dalam Pembelajaran PAI. TA'ALLUM: Jurnal Pendidikan Islam Vol. 06, No. 01 Juni 2018 Hal 83-104

Noer, M. 2010. Hypnoteaching for Succes Learning. Yogyakarta: PT Pustaka Intan Madani

Novak, J.D. \& Gowin, B. D. 2004. Learning How To Learn. Cambridge University Press.

Ramadhan, M. D., \& Winaryati, E. 2016. Korelasi Metode Pembelajaran Terhadap Mindset Siswa pada Pelajaran Kimia. Jurnal Pendidikan Sains Universitas Muhamadiyah Semarang Volumen 04 Nomor 01 Maret 2016

Taylor, E. W., \& Cranton, P. (2013). A Theory in Progress? Issues in Transformative Learning. Europan Journal for Research on the Education and Learning of Adults, Vol.4, No. 1, 2013, pp. 33-47

Zhang R. (2009) Data Reduction. In: LIU L., ÖZSU M.T. (eds) Encyclopedia of Database Systems. Springer, Boston, MA. https://doi.org/10.1007/978-0-387-399409_533 
AKSARA: Jurnal Ilmu Pendidikan Nonformal

P-ISSN $\underline{2407-8018}$ E-ISSN $\underline{2721-7310}$ DOI prefix $\underline{10.37905}$

Volume 07 (02) Mei 2021

http://ejurnal.pps.ungac.id/index.php/Aksara

412 AKSARA: Jurnal Ilmu Pendidikan Nonformal 